\title{
Dinuclear Ternary Copper(II) Complex: Synthesis, Characterization, Structure and DNA-Binding Studies
}

\author{
Muhammad Iqbal, ${ }^{1,}$ Afifa Mushtaq, ${ }^{2}$ Saqib Ali, ${ }^{2,}{ }^{\star}$ Manzar Sohail $^{3}$ \\ and Paul A. Anderson ${ }^{4}$ \\ ${ }^{1}$ Department of Chemistry, Bacha Khan University, Charsadda 24420, KPK, Pakistan \\ ${ }^{2}$ Department of Chemistry, Quaid-i-Azam University, Islamabad 45320, Pakistan \\ ${ }^{3}$ Department of Chemistry, School of Natural Sciences, National University of Science and Technology, \\ H-12, Islamabad 44000, Pakistan. \\ ${ }^{4}$ School of Chemistry, The University of Birmingham, Edgbaston, Birmingham, B15 2TT, U.K. \\ *Corresponding authors: E-mail: iqbalmo@yahoo.com, iqbal@bkuc.edu.pk (M. Iqbal) \\ Tel.: +9291 6002934; fax: +92916540060. \\ drsa54@hotmail.com, saqibali@qau.edu.pk(S.Ali) \\ Tel.: +92 51 90642130; fax: +925190642241.
}

Received: $30-08-2018$

\begin{abstract}
A dinuclear centrosymmetric copper(II) complex has been prepared and characterized via FT-IR, UV-Visible and electron spin resonance spectroscopy, electrochemical method, and powder and single crystal XRD techniques. The two copper(II) ions are connected by two $\mu-1,1-\mathrm{O}$ atoms belonging to para-fluorophenyl acetate ligands. Each copper(II) ion is coordinated by two other carboxylate ligands in monodentate and a 2,2'-bipyridine molecule in bidentate manner. Thus the geometry around each penta-coordinated copper(II) ion is square pyramidal with distortion factor $\tau=0.04$. Purity and uniform crystalline nature of the complex was assessed from powder XRD spectrum. ESR signal consisted of partially resolved hyperfine splitting pattern while electrochemical studies revealed diffusion controlled electron transfer processes with diffusion co-efficient of $1.628 \times 10^{-7} \mathrm{~cm}^{2} \mathrm{~s}^{-1}$. The results of all spectroscopic experiments support each other. The complex afforded mixed binding mode with DNA yielding DNA-binding constant values of $3.667 \times 10^{4}$ and $1.438 \times 10^{4} \mathrm{M}^{-1}$ using cyclic voltammetry and absorption spectroscopy, respectively. The preliminary studies heralded good structural and biological importance of the synthesized complex.
\end{abstract}

Keywords: Oxygen-bridged copper complex; structure; electrochemistry; DNA-binding study.

\section{Introduction}

Binuclear copper(II) carboxylates with 2,2'-bipyridine adopt diverse bridging groups which affect their properties. There can be single bridging group such as a trans-bidentate ligand like 1,4-dibenzoate ion. ${ }^{1}$ Such relatively longer spacer ligand precludes the possibility of electronic interaction between two copper(II) ions of the binuclear molecule. In such binuclear copper(II) complexes the observed EPR signal is typical of monomeric complexes with $\mathrm{g} \sim 2 .^{2}$ Another common bridging group in binuclear copper(II) complexes is chlorine ${ }^{3}$ where the di- chloro-bridged dinuclear complexes with 2,2'-bipyridine were found catalytically more active than their mono-nuclear analogue. ${ }^{3}$ Some complexes contain water molecules bridging the two copper(II) centers ${ }^{4}$ where the weaker super-exchange interactions in analogues containing 1,10-phenanthroline and 2,2'-bipyridine have been attributed to the diauqa bridges.

Carboxylate ligand is known for its versatile binding as well as bridging mode. Although the 1,2-bridging mode of carboxylate ${ }^{5}$ as well as thio-carboxylate ligand ${ }^{6}$ is common, it is also able to bridge two metal centers of dinuclear complexes in 1,1-O-bridging fashion as in phenyl acetate 
and maleate derivatives of copper(II) with $2,2^{\prime}$-bipyridine. ${ }^{7,8}$ The latter type of bridging can be alone ${ }^{7}$ or in combination with other 1,1-bridging groups. The other 1,1-bridging groups can be hydroxyl, aquo ${ }^{9}$ and $\mathrm{Cl}^{10}$ along with a variety of 1,2-bridging groups. These groups have been found to alter the properties of the resulting complexes considerably. This paper reports the synthesis, characterization and DNA-binding properties of a double 1,1-O-bridging copper(II) carboxylate containing biologically important ligand $2,2^{\prime}$-bipyridine.

\section{Experimental}

\section{1. Materials and Methods}

Anhydrous $\mathrm{CuSO}_{4}$, 4-fluorophenyl acetic acid, 2,2'bipyridine, $\mathrm{KCl}, \mathrm{NaHCO}_{3}$ and sodium salt of the salmon sperm DNA were purchased from Fluka, Switzerland. Solvents like chloroform, methanol and dimethyl sulfoxide were obtained from Merck, Germany. Melting point was measured using an electro-thermal melting point apparatus Gallenkamp, serial number C040281, U.K. FT-IR spectrum was recorded in the range from 4000 to $400 \mathrm{~cm}^{-1}$ on a Nicolet-6700 FT-IR spectrophotometer, Thermo Scientific, USA, equipped with attenuated total reflectance (ATR) sampling technique. Powder XRD spectrum was obtained at $298 \mathrm{~K}$ with a PANalytical, XPert PRO diffractometer employing Cu-Ka radiation $(\lambda=1.540598 \AA$ A $)$. Bruker ESP-300 spectrometer operating at X-band frequencies $(-9.5 \mathrm{GHz})$ was used to obtain the solid state EPR spectrum of the finely powdered single crystalline sample of the complex.

\section{2. Single crystal $X$-ray Crystallography}

Diffraction data for the complex were collected at the Australian Synchrotron $(\lambda=0.708457 \AA)$ at $100(2) \mathrm{K}$ on beamline MX1. ${ }^{11}$ XDS software was used for the data reduction and indexing of diffraction pattern. ${ }^{12}$ Direct method was used to solve the crystal structure while using the program SHELXL-97, it was refined against $\mathrm{F}^{2}$ with full-matrix least-squares method. ${ }^{13}$ Refinement of all non-hydrogen atoms was performed with anisotropic displacement parameters.

\subsection{Electrochemical Study}

Voltammetric study was conducted using an SP-300 potentiostate, serial number 0134, BioLogic Scientific Instruments, France. Complex was dissolved in aqueous DMSO (1:4) solution containing $0.01 \mathrm{M} \mathrm{KCl}$, under an $\mathrm{N}_{2}$ saturated environment. Measurements were made in a conventional three-electrode cell with a thin platinum wire as counter electrode, a bare glassy carbon electrode (GCE) with a surface area of $0.196 \mathrm{~cm}^{2}$ as the working electrode and saturated silver/silver chloride electrode $(\mathrm{Ag} / \mathrm{AgCl})$ as reference electrode. Prior to each experi- ment, the GCE was cleaned properly such as polishing with alumina $\left(\mathrm{Al}_{2} \mathrm{O}_{3}\right)$ and washing with organic solvent and distilled water. All the measurements were performed at room temperature $\left(25 \pm 0.5{ }^{\circ} \mathrm{C}\right)$.

\section{4. DNA-Binding Study by Cyclic Voltammetry}

The salmon sperm DNA (SSDNA) solution was prepared by overnight stirring of the solution after adding small amount of its sodium salt to it. Then its absorption spectrum was taken and concentration of DNA was calculated using Beer-Lambert's law putting molar absorptivity $=6600 \mathrm{M}^{-1} \mathrm{~cm}^{-1} \cdot{ }^{14}$ Complex solution was prepared at 3 $\mathrm{mM}$ in aqueous DMSO (1:4) and its voltammograms were recorded in pure form as well as with 10, 20, 30, 40, 50 and $60 \mu \mathrm{M}$ DNA.

\section{5. DNA-Binding Study by UV-Visible Spectroscopy}

The complex was prepared at $6 \mathrm{mM}$ in aqueous DMSO (1:4) and its absorption spectra were taken in pure from as well as in the presence of 10-90 $\mu \mathrm{M}$ DNA. Successive additions of SSDNA were made to the reference as well as sample cells ( $1 \mathrm{~cm}$ path length) and the spectra recorded at room temperature $\left(25 \pm 1^{\circ} \mathrm{C}\right)$.

\section{6. Synthetic Procedure of the Complex}

4-Fluorophenyl acetic acid ( $6 \mathrm{mmol}, 0.925 \mathrm{~g}$ ) was neutralized via reacting with an equimolar quantity of sodium bicarbonate $(0.504 \mathrm{~g}, 6 \mathrm{mmol})$ in distilled water. After neutralization, copper sulphate $(0.240 \mathrm{~g}, 3 \mathrm{mmol})$ was added to the reaction mixture and was stirred for $3 \mathrm{~h}$ at 60 ${ }^{\circ} \mathrm{C}$ as depicted in Scheme 1. This was followed by the addition of solid 2,2'-bipyridine $(0.468 \mathrm{~g}, 3 \mathrm{mmol})$ and stirring was continued for further $3 \mathrm{~h}$. The final product was washed with distilled water and dried in air. A mixture of chloroform and methanol (1:1) was used for crystallization.

Light blue crystals; m.p. $150-152{ }^{\circ} \mathrm{C}$; yield $(70 \%)$. FT-IR $\left(\mathrm{cm}^{-1}\right): 1614 v(\mathrm{OCO})_{\text {asym }}, 1421 v(\mathrm{OCO})_{\text {sym }}, \Delta v=$ 193, $2955 v \mathrm{CH}_{2}, 3084 v(\mathrm{Ar}-\mathrm{H}), 1590,1473 v \mathrm{Ar}(\mathrm{C}=\mathrm{C})$, $1217 v(\mathrm{Ar}-\mathrm{F}), 421 v(\mathrm{Cu}-\mathrm{O}), 506 v(\mathrm{Cu}-\mathrm{N})$.

\section{Results and Discussion}

Copper(II) complex with 4-fluorophenyl acetic acid and 2,2'-bipyridine has been isolated in quantitative yield by following Scheme 1. The complex has been characterized by various analytical techniques such as infra-red, UV-Visible and electron spin resonance spectroscopy as well as powder and single crystal X-ray diffraction while the purity level of the complex was confirmed by powder 
<smiles>O=C(O)CCCCCCCCCCCNC(=O)c1ccc(F)cc1</smiles><smiles>O=C(Cc1ccc(F)cc1)O[Na]</smiles>

$3 \mathrm{hr}$ stirring followed by addition of 2,2'-bipyridine

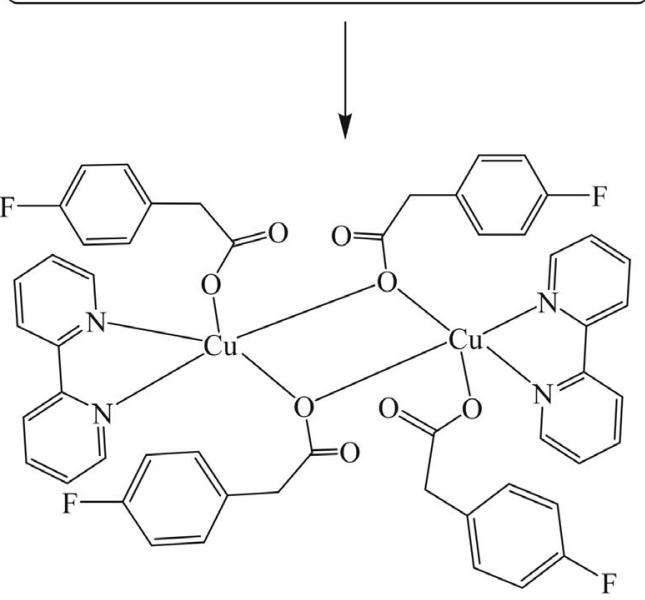

Scheme 1. Synthetic procedure of the complex

XRD pattern. DNA binding constant for the complex were evaluated, using cyclic voltammetry and UV-Visible spectrophotometry.

\section{1. FT-IR Data}

FT-IR spectrum of the complex showed all the expected bands which helped to deduce its structure. The bonding mode of the carboxylate moiety was indicated by its characteristic stretching frequency observed at 1614 and $1421 \mathrm{~cm}^{-1}$ corresponding to the asymmetric and symmetric OCO stretching vibrations, respectively. The appearance of a $\mathrm{Cu}-\mathrm{O}$ absorption band at $421 \mathrm{~cm}^{-1}$ confirmed the coordination of the carboxylate ligands through oxygen. The values of $\Delta v=\left\{v_{\text {asym }}(\mathrm{OCO})-v_{\text {sym }}(\mathrm{OCO})\right\}=$ 193 calculated for the complex indicated bridging bidentate mode of coordination of the carboxylate moiety to copper(II) ion in the complex. ${ }^{15}$ In addition, the appearance of $\mathrm{C}=\mathrm{N}$ stretching band of the complex at $1598 \mathrm{~cm}^{-1}$ instead of its normally observed characteristic region (1610-1625 $\left.\mathrm{cm}^{-1}\right)^{16,17}$ indicated the involvement of the nitrogen atom of bipyridine in bonding with copper(II) ion. ${ }^{18}$ The appearance of a new medium intensity band for the complex in the region $506 \mathrm{~cm}^{-1}$, attributable to a $\mathrm{Cu}-\mathrm{N}$ vibration further supported it. ${ }^{19}$ The aromatic $\mathrm{C}=\mathrm{C}$ and $\mathrm{C}-\mathrm{H}$ stretching vibrations were observed at 1590, 1473 and $3084 \mathrm{~cm}^{-1}$, respectively. The methylene $\mathrm{C}-\mathrm{H}$ stretching frequency of the complex was observed at $2955 \mathrm{~cm}^{-1}$ which were supported by the presence of bands at 730 and $1359 \mathrm{~cm}^{-1}$ corresponding to its rocking and bending vibrations, respectively. Methyl $\mathrm{C}-\mathrm{H}$ stretching frequency gave rise to absorption band at $2985 \mathrm{~cm}^{-1}$ supported by the band at $1443 \mathrm{~cm}^{-1}$ assignable to the bending vibrational motion of this functionality. Aromatic $\mathrm{C}-\mathrm{F}$ was indicated by well-defined peak at $1217 \mathrm{~cm}^{-1}$.

According to the literature, 2,2'-bipyridine and 1,10-phenanthroline give rise to absorption bands at 756, $851,1090,1138,1274,1434$ and $3337 \mathrm{~cm}^{-1} .{ }^{20}$ Keeping in view these absorption values, the bands appearing at 3329, $1275,1167,1090$ and $775 \mathrm{~cm}^{-1}$ have been assigned to the coordinated 2,2'-bipyridine molecule. The presence of lattice water molecules was indicated by a broad absorption band at $3200-3600 \mathrm{~cm}^{-1}$.

\section{2. Powder XRD Study}

Powder X-ray diffraction spectrum of the synthesized complex has been obtained and compared with the respective simulated spectrum of the complex by superimposing the spectra. The experimental and simulated powder XRD spectra are in complete agreement mutually as shown in Fig. 1, indicating that the complex has been isolated and crystallized in completely pure form.
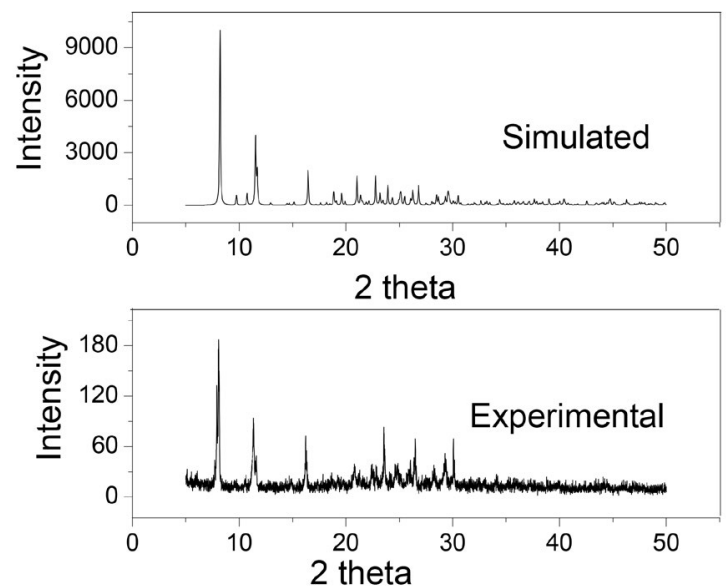

Figure 1. Experimental and simulated powder XRD spectra of the complex.

\section{3. ESR Spectroscopy}

X-band ESR spectrum of crystalline sample of the complex in solid state is shown in Fig. 2A. The spectrum is typical of dinuclear copper(II) complexes in triplet state $e^{21}$ showing partially resolved hyperfine splitting with $\mathrm{g}^{\perp}$ values 2.23603 and 1.95253 indicating dimeric structure for the 

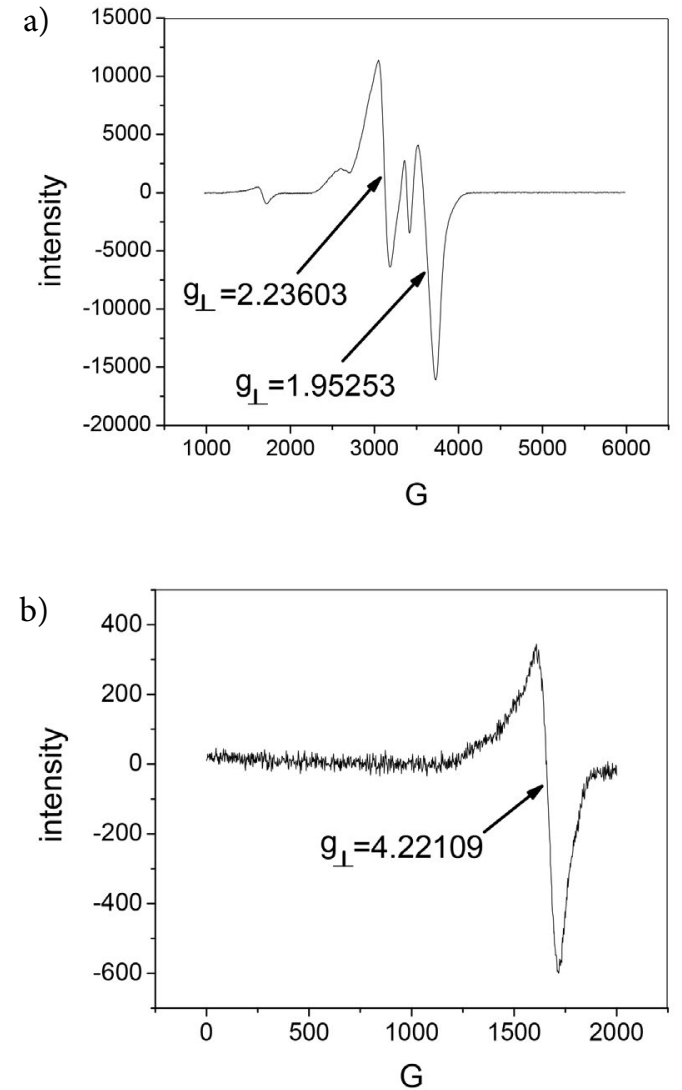

Figure 2. A, X-Band ESR spectrum of complex showing partially resolved hyperfine splitting. $\mathrm{B}$, low field spectrum showing the 'half-filled' forbidden transition.

complex in solid state. ${ }^{21,22}$ The low field spectrum shown in Fig. 2B indicates the 'half-filled' forbidden transition. ${ }^{21}$ Thus the typical ESR signal confirmed the +2 oxidation state of copper in the complex and supported the nuclearity and structure of the synthesized copper(II) complex.

\section{4. Structural Description of the Complex}

The ORTEP diagram with the atom numbering scheme of the complex is shown in Fig. 3, while the crystal data and refinement parameters are given in Tables 1 and 2. In the dinuclear complex, the two copper(II) ions are connected by two $\mu-1,1-\mathrm{O}$ atoms belonging to carboxylate ligands. Each copper(II) ion is coordinated by two other carboxylate ligands in monodentate and a 2,2'-bipyridine molecule in bidentate manner. This results in square pyramidal geometry for each penta-coordinated copper(II) ion. The complex is centrosymmetric in which the metal centers are bridged by $\mu-1,1-\mathrm{O}$ atoms and the center of symmetry is lying at the center of the $\mathrm{Cu}_{2} \mathrm{O}_{2}$ parallelogram core. Constituting the axial position of one square pyramid, each of the bridging oxygen atoms is part of the square plane of the other square pyramid. Each pair of the copper atoms constitutes a four cornered planar $\mathrm{Cu}_{2} \mathrm{O}_{2}$ core where the two bipyridine molecules are trans oriented with respect to the $\mathrm{Cu}_{2} \mathrm{O}_{2}$ core making five-membered chelate rings with $\mathrm{Cu}$. The distortion factor $\tau\left(=\beta-\alpha / 60^{\circ}\right.$, where $\beta$ and $\alpha$ are the largest $\left(174.48(6)^{\circ}\right)$ and second largest $\left(172.31(7)^{\circ}\right)$ angles around the five-coordinated metal ion) calculated for the complex was 0.04, which shows a slightly distorted square pyramidal geometry for each copper(II). ${ }^{23}$ The $\mathrm{Cu}-\mathrm{N}$ bond distances are $1.9999(18)$ and 2.0189(18) A and are similar to the corresponding distances found in previously reported dinuclear copper-bipyridine complexes. ${ }^{24}$

$\mathrm{Cu}-\mathrm{O}$ distances of the complex are quite asymmetrical. The $\mathrm{Cu}-\mathrm{O}$ bond distances in the equatorial plane are 1.9441(16) and 1.9800(15) $\AA$ which are typical of the $\mathrm{Cu}-\mathrm{O}$ equatorial distances of the previously reported dimeric $^{25}$ and polymeric ${ }^{26,27}$ complexes. The axial $\mathrm{Cu}-\mathrm{O}$ distance is $2.3535(15) \AA$ indicating relatively weaker bond with copper. Since copper(II) complexes with square pyramidal geometry are Jahn-Teller inactive, the elongation of the apical $\mathrm{Cu}-\mathrm{O}$ bonds is owing to the filled antibonding $\mathrm{a}_{1}\left(\mathrm{~d}_{\mathrm{z}}^{2}\right.$-orbital) leading to more electron density of the filled antibonding orbital along the apical $\mathrm{Cu}-\mathrm{O}$ bond axis. ${ }^{28}$ The $\mathrm{b}_{1}\left(\mathrm{~d}_{\mathrm{x}}{ }^{2}{ }_{\mathrm{y}}{ }^{2}\right)$ orbital is half filled and is not offering that much repulsion to the four ligands (two $\mathrm{Cu}-\mathrm{O}$ and two $\mathrm{Cu}-\mathrm{N}$ bonds) present in the basal plane. Such elongation of the apical bond has been found typical of the previously reported complexes as well. ${ }^{29}$ The nearly perfect square pyramidal geometry around copper has been made possible by the asymmetric nature of the $\mathrm{Cu}-\mathrm{O}$ bond distance of the bridging oxygen. This $\mathrm{Cu}-\mathrm{O}-\mathrm{Cu}$ asymmetric bonding of the bridging oxygen is also typical of other copper(II) complexes. ${ }^{25}$ The smallest angle around $\mathrm{Cu}$ is $\mathrm{N}-\mathrm{Cu}-\mathrm{N}=80.74(7)^{\circ}$ being formed by the copper ion and two nitrogen atoms of bipyridine molecule and has been found typical of other copper(II) complexes with N- and O-donor ligands. ${ }^{30}$

\section{Packing arrangement:}

The packing diagram of the complex is shown in Fig. 4 , where the uncoordinated oxygen atoms of the carboxyl-

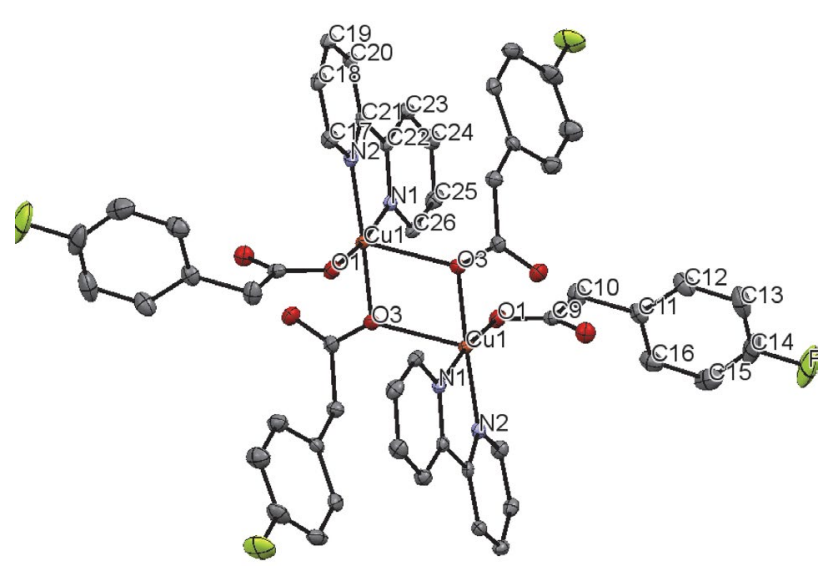

Figure 3. ORTEP drawing of the complex with atom numbering scheme. H-atoms not shown for clarity. 


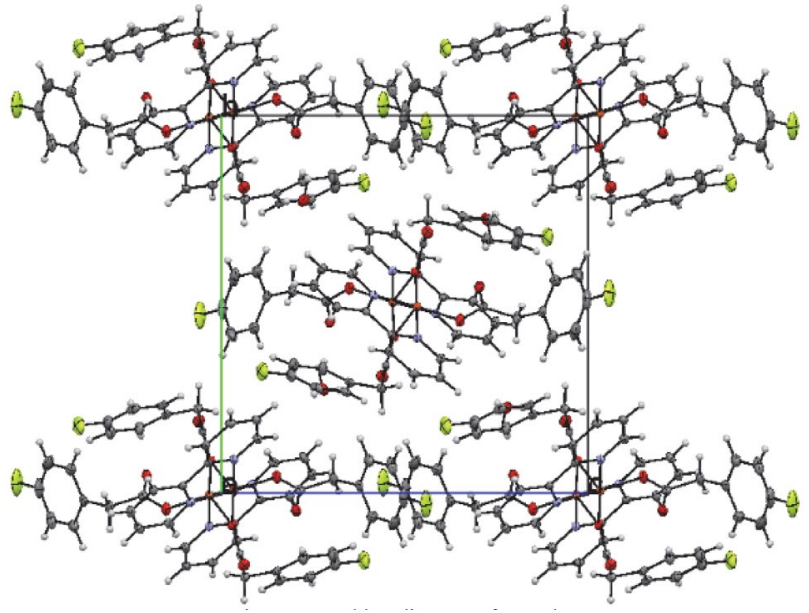

Figure 4. Packing diagram of complex

Table 1. Structure refinement parameters of the dinuclear complex

\begin{tabular}{ll}
\hline Empirical formula & $\mathrm{C}_{52} \mathrm{H}_{44} \mathrm{~F}_{4} \mathrm{Cu}_{2} \mathrm{~N}_{4} \mathrm{O}_{10}$ \\
Formula weight $\left(\mathrm{g} \mathrm{mol}^{-1}\right)$ & 1088.01 \\
$T(\mathrm{~K})$ & $100(2)$ \\
Crystal system & Monoclinic \\
Space group & $P{ }_{1} / n$ \\
Unit cell dimensions & \\
$a(\AA)$ & $9.948(2)$ \\
$b(\AA)$ & $15.335(3)$ \\
$c(\AA)$ & $15.460(3)$ \\
$\alpha\left({ }^{\circ}\right)$ & 90 \\
$\beta\left(^{\circ}\right)$ & $101.58(3)$ \\
$\gamma\left({ }^{\circ}\right)$ & 90 \\
$V\left(\AA^{3}\right)$ & $2310.5(8)$ \\
$Z$ & 2 \\
$\rho($ calculated $)\left(\mathrm{Mg} / \mathrm{m}^{3}\right)$ & 1.564 \\
$\left.\mu(\mathrm{mm})^{-1}\right)$ & 1.004 \\
$F(000)$ & 1116 \\
Reflections collected & 14039 \\
Independent reflections & 4035 \\
Data / restraints / parameters & $4035 / 0 / 405$ \\
Goodness-of-fit on $F^{2}$ & 1.077 \\
Final R indices $[I>2 \sigma(I)]$ & $R_{1}=0.0335, w R_{2}=0.086$ \\
$R$ indices (all data) & $R_{1}=0.0375, w R_{2}=0.0883$ \\
\hline
\end{tabular}

ate ligand establish weaker interactions with the hydrogen atoms of the 2,2'-bipyridine ligand of the side lying dimer and those of the lattice water molecule. Additionally, the water molecule present in the crystal lattice is responsible for strong intermolecular interactions: its oxygen and hydrogen atoms are able to interact with the methylene hydrogen and the uncoordinated oxygen atoms of the carboxylate ligands of the two neighboring dinuclear complexes, respectively, thus completing the packing. Similarly, one out of two fluorine atoms of each of the two asymmetric units of the dimeric molecules of the complex is closer enough to attract methylene hydrogen atoms of a ligand in the next dimer.
Table 2. Selected bond lengths and angles of the dinuclear complex

\begin{tabular}{lr}
\hline Distances, $\mathbf{\AA}$ & \\
\hline N1-Cu1 & $1.9999(18)$ \\
N2-Cu1 & $2.0189(18)$ \\
O1-Cu1 & $1.9441(16)$ \\
O3-Cu1 & $1.9800(15)$ \\
Cu1-O3 & $2.3535(15)$ \\
\hline Angles, ${ }^{\circ}$ & \\
\hline O1-Cu1-O3 & $91.69(7)$ \\
O1-Cu1-N2 & $172.31(7)$ \\
O3-Cu1-N2 & $95.51(7)$ \\
O1-Cu1-N1 & $91.89(7)$ \\
O3-Cu1-N1 & $174.48(6)$ \\
N2-Cu1-N1 & $80.74(7)$ \\
O1-Cu1-O3 & $90.41(6)$ \\
O3-Cu1-O3 & $77.84(6)$ \\
N2-Cu1-O3 & $93.76(6)$ \\
N1-Cu1-O3 & $106.33(6)$ \\
\hline
\end{tabular}

\section{5. DNA Binding Study Through Cyclic Voltammetry}

DNA binding ability of the complex has been explored using cyclic voltammetry where the shift of peak potential was used to interpret the mode of DNA binding activity of the complex. According to literature, shifting of potential to the less positive region on addition of DNA exhibits electrostatic mode of interaction with complex, ${ }^{31,32}$ while to a more positive region indicates intercalative mode. However, a mixed DNA-complex binding behavior is usually observed in practice. Based on the above criteria, a mixed binding mode has been observed for the synthesized complex. A shift of $40 \mathrm{mV}$ in the potential to the less positive region was observed on addition of DNA to the complex solution as shown in Fig. 5A, exhibiting an electrostatic mode of interaction with the complex. ${ }^{31}$ However, after successive addition of SSDNA, the potential kept shifting to the right side which shows a concomitant intercalative mode of binding with SSDNA as well. The intercalative ability of the complex is attributed to the homo- as well as heterocyclic aromatic rings in the molecular structure of the complex while the concomitant electrostatic mode is owing to the presence of florine atoms at the para-position of the phenyl rings which are able to establish electrostatic interaction with DNA base pairs. In short, the presence of polar as well as planar groups give rise to a mixed DNA binding mode. Since the shift in peak potential towards less positive region is far more compared to the shift towards more positive region, the major mode of binding will be electrostatic.

The diminution in the peak current as a consequence of DNA addition to the complex solution as evident from Fig. 5 (inset) is attributed to the decrease in concentration of the free complex as a result of the formation of complex-DNA adduct. The slope value of $i_{p} v s$. 

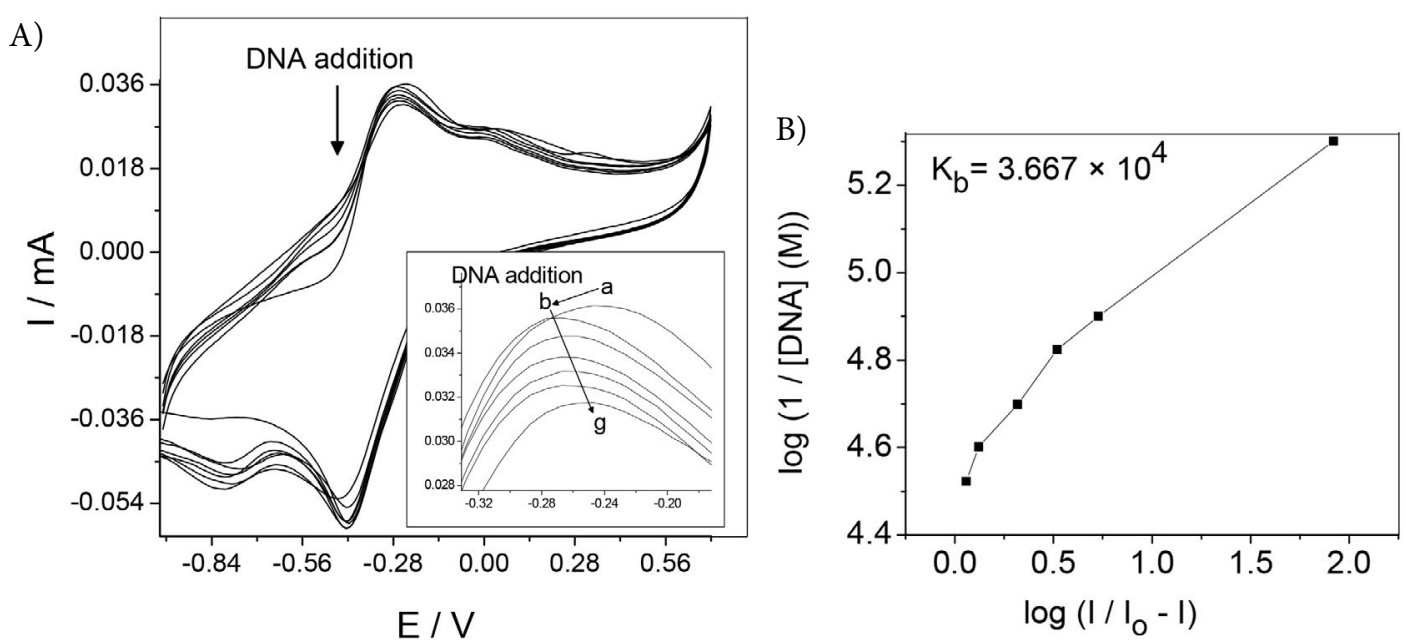

Figure 5. A, Cyclic voltammograms of the complex in the absence and presence of 10-60 $\mu \mathrm{M}$ DNA. The peak current decreases and the peak potential is shifted to the right hand side on successive additions of DNA as shown in inset. B, plot of log. 1/[DNA] vs. log. $I /($ Io $-I)$ for the calculation of binding constant of complex through cyclic voltammetry.

A)

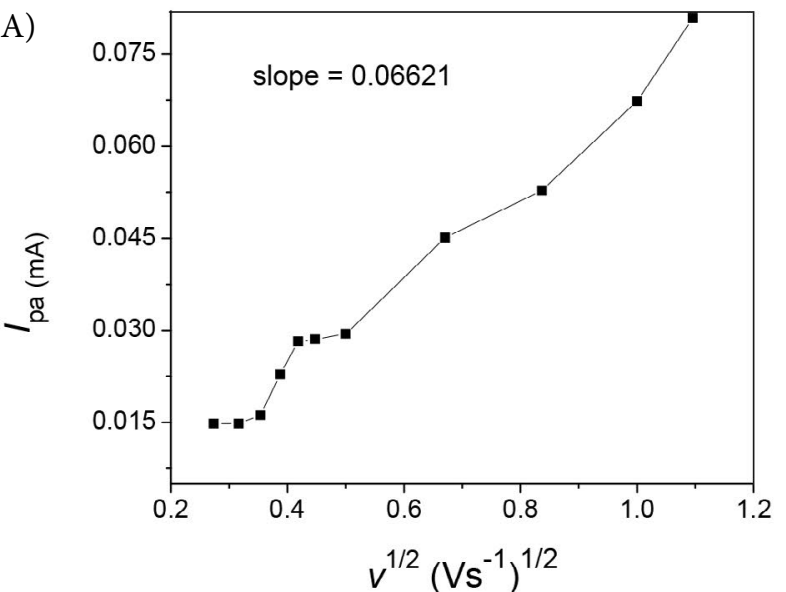

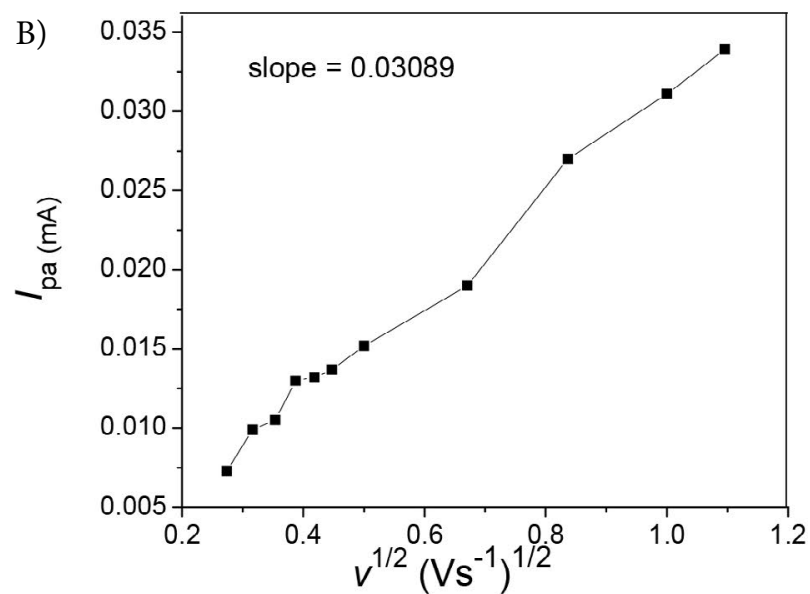

Figure 6. Plots of anodic peak current, $i_{p} v s$. square root of scan rate, $v^{1 / 2}$ before (A) and after (B) DNA addition showing reduction in slope value with DNA addition.

$v^{1 / 2}$ plot is reduced from 0.066 to 0.030 on addition of DNA as shown in Fig. 6 indicating the binding of DNA with complex. ${ }^{33,34}$ This decrease was used as basis for the calculation of binding constant of the complex with DNA making use of the straight line plot of $\log 1 /[\mathrm{DNA}] v s$. $\log I /\left(I_{\mathrm{o}}-I\right)$ (Fig. 5B), using the following equation (equation 3.1): ${ }^{35}$

$$
\log (1 /[\mathrm{DNA}])=\log K_{b}+\log I /\left(I_{\mathrm{o}}-I\right)
$$

where $K_{b}$ is the binding constant, $I_{\mathrm{o}}$ and $I$ are the peak currents of the complex in the absence and presence of DNA, respectively. The value of $\mathrm{K}_{\mathrm{b}}$ was found to be $3.667 \times 10^{4}$ $\mathrm{M}^{-1}$ which is comparable to other structurally related copper(II) ${ }^{36,37}$ and $\mathrm{Rh}(\mathrm{II})^{38}$ complexes.

Since the electro-active complex moves to the electrodes via diffusion, its diffusion coefficient $\mathrm{D}_{\mathrm{o}}$ should suffer diminution with DNA addition. $\mathrm{D}_{\mathrm{o}}$ was calculated using the Randles-Sevcik equation ${ }^{39}$ (equation 3.2) via putting various parameters in it and measuring voltammograms at different scan rates before and after DNA addition.

$$
i_{\mathrm{p}}=\left(2.99 \times 10^{5}\right) \mathrm{n}(\mathrm{an})^{1 / 2} \mathrm{AC}^{*} \mathrm{D}_{\mathrm{o}}^{1 / 2} v^{1 / 2}
$$

where $i_{\mathrm{p}}, \mathrm{n}, \alpha, \mathrm{A}, \mathrm{C}^{*} \mathrm{D}_{\mathrm{o}}$ and $v$ denote the peak current in ampere, the number of electrons involved charge transfer coefficient, surface area of electrode, molar concentration of complex, diffusion coefficient in $\mathrm{cm}^{2} \mathrm{~s}^{-1}$ and scan rate in $\mathrm{V} \mathrm{s}^{-1}$, respectively.

The slope value was obtained making use of the respective $i_{\mathrm{p}} v s . v^{1 / 2}$ plots for oxidation and reduction while Bard and Faulkner relation ${ }^{40}$ (equation 3.3) was used to calculate an.

$$
\text { an }=47.7 /\left[\mathrm{E}_{\mathrm{p}}-\mathrm{E}_{\mathrm{p}} / 2\right] \mathrm{mV}
$$


where $E_{p}$ is the peak potential and $E_{p} / 2$ is the peak potential at half of the maximum peak current value. The values of $D_{o}$ thus calculated for the complex before and after DNA addition are $28.255 \times 10^{-8}$ and $8.413 \times 10^{-8} \mathrm{~cm}^{2} \mathrm{~s}^{-1}$. The higher value of $\mathrm{D}_{0}$ of the free complex shows higher mobility of the complex before DNA addition which indicates the interaction of complex and DNA. ${ }^{41,42}$ Thus the voltammetric study indicated the potent DNA-binding potency of the complex.

\section{6. Absorption Spectroscopy}

The complex showed a broad band in the visible region of the electromagnetic spectrum with $\lambda_{\max }=680 \mathrm{~nm}$ attributed to $\mathrm{d}$ - $\mathrm{d}$ transition of $\mathrm{Cu}^{2+43,44}$ which is typical of geometrically similar copper(II) complexes and helped to confirm the structure of the complex in solution. Such broad absorption band with $\lambda_{\max }=680 \mathrm{~nm}$ is typical of a distorted octahedral geometry in solution as shown in Fig. $7 \mathrm{~A}$ (peak a). This indicates the attachment of a DMSO molecule to the square pyramidal copper in the complex. According to the literature, other copper(II) complexes of similar geometry have been found to show absorbance in the same wave length region. ${ }^{45,46}$ Using Beer-Lambert's law, $\varepsilon$ of the complex was calculated to be $193 \mathrm{~L} \mathrm{~mol}^{-1} \mathrm{~cm}^{-1}$ which is of the same magnitude as those of the structurally related copper(II) complexes. ${ }^{43}$

\section{7. DNA Study Through Absorption Spectroscopy}

Since the absorption of the complex depends on concentration, variation of absorbance of complex is a sensitive method of DNA-binding activity. Shift in $\lambda_{\max }$ as well as reduction in absorbance are accompanied with binding of the complex with DNA. When $\lambda_{\max }$ is shifted towards shorter wavelength side, an electrostatic mode is manifested while intercalative mode is exhibited by shift towards longer wavelengths. ${ }^{47,48}$ Absorbance of the synthesized complex exhibited marked decrease with addition of DNA
(10-90 $\mu \mathrm{M})$ along with small red shift of $4 \mathrm{~nm}$ as indicated in its spectrum shown in Fig. 7A. This type of binding has been termed as 'mixed binding mode' i.e., partial intercalation with groove binding mode.

The decrease in absorbance as a result of DNA addition gave the basis for quantitative affinity of copper(II) complex for DNA by calculating its binding constant $\mathrm{K}_{\mathrm{b}}$ using the famous Benesi-Hildebrand equation ${ }^{49}$ (equation 3.4):

$$
\frac{A_{o}}{A-A_{o}}=\frac{\varepsilon_{G}}{\varepsilon_{H-G}-\varepsilon_{G}}+\frac{\varepsilon_{G}}{\varepsilon_{H-G}-\varepsilon_{G}} \frac{1}{K[D N A]}
$$

where $A$ and $A_{o}$ are the absorbance of the complex in the presence and absence of DNA while $\varepsilon_{\mathrm{H}-\mathrm{G}}$ and $\varepsilon_{\mathrm{G}}$ are their absorption coefficients, respectively. The ratio of slope to intercept of the plot of the term on the left-hand side of equation 3.4 vs. 1/[DNA] gives $\mathrm{K}_{\mathrm{b}}$ as shown in Fig. 7B.

The binding constant value of the complex was $1.438 \times$ $10^{4} \mathrm{M}^{-1}$ which is of the same order of magnitude as that calculated using cyclic voltammetry. The para-fluoro group on the phenyl ring and the planar aromatic rings may be responsible for the facile DNA-binding ability of the complex. Similar binding potency has been observed for other copper(II) complexes as well. ${ }^{50,51}$ Thus the results of the absorption spectroscopy and cyclic voltammetry for the DNA-binding potency are in support of each other. The DNA-binding ability of the complex explored through these two techniques heralds the biological relevance of the synthesized complex.

\section{Conclusion}

Mixed N- and O-donor ligand copper(II) carboxylate complex has been synthesized, isolated and purified in quantitative yield. Its characterization has been confirmed through single crystal XRD while the purity level was evaluated by superimposing the simulated and experimental powder XRD plots which were found in complete agreement showing that the crystalline sample was composed of
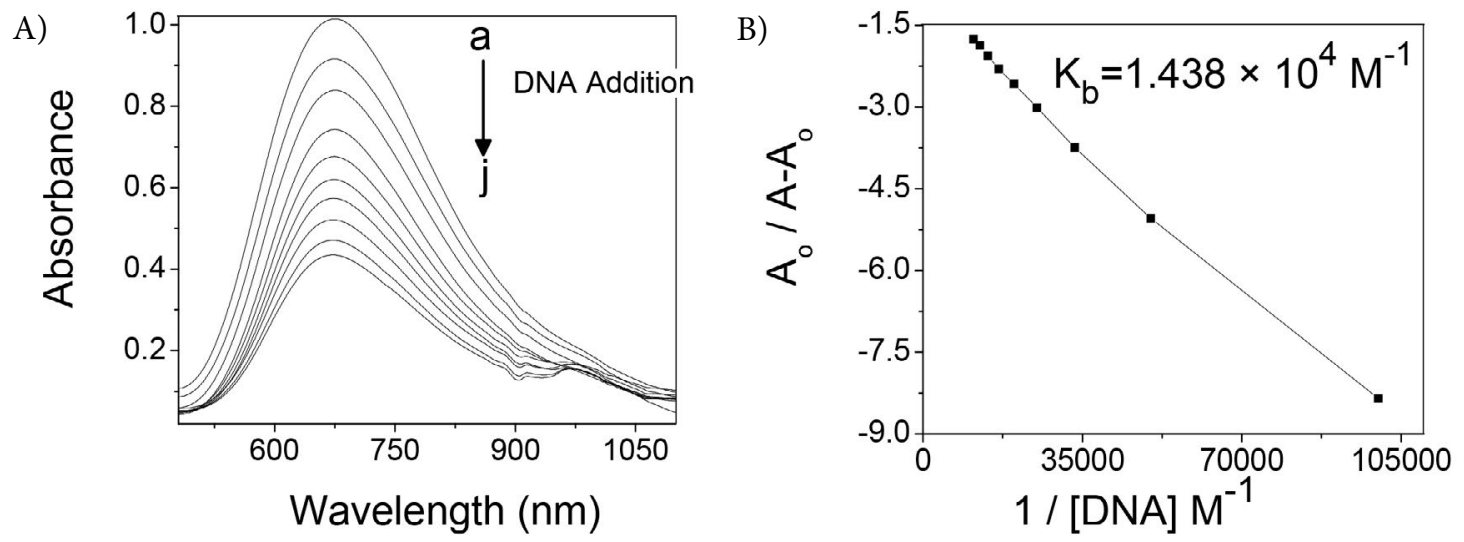

Figure 7. A, Absorption spectra of complex. Peak a indicates spectrum of pure complex while other peaks (b-j) are after DNA addition (10-90 $\mu \mathrm{M})$. B, Plot of $A_{\mathrm{o}} /\left(A-A_{\mathrm{o}}\right) v s .1 /[\mathrm{DNA}]$ for the calculation of binding constant of complex through absorption spectroscopy. 
the single crystalline phase without any other impurity. Crystal structure has shown that the geometry around copper(II) ion is square pyramidal in the dinuclear complex with asymmetrically bridging oxygen atom. The DNA binding ability of the complex was judged from CV and UV-Visible spectroscopy by calculating the intrinsic binding constant of the complex with DNA from both techniques. Both techniques resulted in $\mathrm{K}_{\mathrm{b}}$ values of the same order of magnitude such as $3.667 \times 10^{4}$ and $1.438 \times 10^{4}$ $\mathrm{M}^{-1}$, respectively. Moreover, the reduction of the diffusion co-efficient of the complex on addition of DNA further supported the DNA binding ability of the complex.

Supplementary material: CCDC 890111 contains all the crystallographic information about the synthesized complex. The data is accessible at http://www.ccdc.cam. ac.uk/conts/retrieving.html, or from the Cambridge Crystallographic Data Centre, 12 Union Road, Cambridge CB2 1EZ, UK; fax: +44 1223336 033; or e-mail: deposit@ccdc. cam.ac.uk.

\section{Acknowledgements}

M.I. is thankful to Dr. Paul W. Davies and Mr. Terry Green for ESR spectra obtained at School of Chemistry, The University of Birmingham, Edgbaston, Birmingham, B15 2TT, U.K

\section{References}

1. W. Huang, D. Hu, S. Gou, H. Qian, H.-K. Fun, S. S. S. Raj, Q. Meng, J. Mol. Struct. 2003, 649, 269-278.

DOI:10.1016/S0022-2860(03)00080-2

2. T.-D. Shfith, J.R. Pitbrow, Coord. Chem. Rev. 1974, 13, 173278. DOI:10.1016/S0010-8545(00)80255-6

3. E. Liu, Y.Z. Zhang, L. Li, C. Yang, J.C. Fettinger, G. Zhang, Polyhedron 2015, 99, 223-229.

DOI:10.1016/j.poly.2015.07.080

4. K. C. Thatipamula, G. Bhargavi, M. V. Rajasekharan, Polyhedron 2015, 97, 182-187. DOI:10.1016/j.poly.2015.05.027

5. A. Mushtaq, S. Ali, M. Iqbal, M. N. Tahir, H. Ismail, J. Chem. Soc. Pak. 2017, 39, 471-477.

6. G. A. van Albada, I. Mutikainen, U. Turpeinen, J. Reedijk, Inorg. Chim. Acta 2001, 324, 273-277.

DOI:10.1016/S0020-1693(01)00613-2

7. M. Iqbal, S. Ali, M. N. Tahir, N. Muhammad, N. A. Shah, M. Sohail, V. Pandarinathan, J. Mol. Struct. 2015, 1093, 135-143. DOI:10.1016/j.molstruc.2015.03.058

8. K. N. Lazarou, V. Psycharis, S. P. Perlepes, C. P. Raptopoulou, Polyhedron 2009, 28, 1085-1096.

DOI:10.1016/j.poly.2009.01.023

9. S. D. Kurbah, A. Kumar, I. Syiemlieh, A. K. Dey, R. A. Lal, J. Mol. Struc. 2018, 1154, 535-542.

DOI:10.1016/j.molstruc.2017.10.054

10. S. Youngme, J. Phatchimkun, N. Wannarit, N. Chaichit, S.
Meejoo, G. A. van Albada, J. Reedijk, Polyhedron 2008, 27, 304-318. DOI:10.1016/j.poly.2007.09.009

11. T. M. McPhillips, S. E. McPhillips, H. J. Chiu, A. E. Cohen, A. M. Deacon, P. J. Ellis, E. Garman, A. Gonzale, N. K. Sauter, R. P. Phizackerley, S. M. Soltis, P. Kuhn, J. Synchrotron. Rad. 2002, 9, 401-406. DOI:10.1107/S0909049502015170

12. W. Kabsch, Acta Cryst. D 2010, 66, 125-132. DOI:10.1107/S0907444909047337

13. G. M. Sheldrick, Acta Cryst. A 2008, 64, 112-122. DOI:10.1107/S0108767307043930

14. C. V. Sastri, D. Eswaramoorthy, L. Giribabu, B. G. Maiya, J. Inorg. Biochem. 2003, 94, 138-145. DOI:10.1016/S0162-0134(02)00622-0

15. S. Leconte, R. Ruzziconi, J. Fluorine Chem. 2002, 11, 167-172. DOI:10.1016/S0022-1139(02)00161-6

16. K. V. Shuvaev, S. Sproules, J. M. Rautiainen, E. J. L. McInnes, D. Collison, C. E. Anson, A. K. Powell, Dalton Trans. 2013, 42, 2371-2381. DOI:10.1039/C2DT31946B

17. C. Jayabalakrishnan, K. Natarajan, Transit. Met. Chem. 2002, 27, 75-79. DOI:10.1023/A:1013437203247

18. Z. H. Abd El-Wahab, M. M. Mashaly, A. A. Salman, B. A. El-Shetary, A. A. Faheim, Spectrochim. Acta A 2004, 60, 2861-2873. DOI:10.1016/j.saa.2004.01.021

19. M. Shakir, N. Begum, S. Parveen, P. Chingsubam, S. Tabassum, Synth. React; Inorg; Met. Org. Chem. 2004, 34, 11351148. DOI:10.1081/SIM-120039262

20. A. Hangan, A. Bodoki, L. Oprean, G. Alzuet, M. Liu-González, J. Borrás, Polyhedron 2010, 29, 1305-1313.

DOI:10.1016/j.poly.2009.12.030

21. K. C. Thatipamula, G. Bhargavi, M. V. Rajasekharan, Polyhedron 2015, 97, 182-187. DOI:10.1016/j.poly.2015.05.027

22. I. Banerjee, P. N. Samanta, K. K. Das, R. Ababei, M. Kalisz, A. Girard, C. Mathonière, M. Nethaji, R. Clérac, M. Ali, Dalton Trans. 2013, 42, 1879-1892. DOI:10.1039/C2DT30983A

23. A.W. Addison, T. N. Rao, J. Reedijk, J. van Rijn, G. C. Verschoor, J. Chem. Soc. Dalton Trans. 1984, 1349-1356.

DOI:10.1039/DT9840001349

24. F. Xu, T. Tao, K. Zhang, X.-X. Wang, W. Huang, X.-Z. You, Dalton Trans. 2013, 42, 3631-3645.

DOI:10.1039/c2dt32281a

25. A. Mushtaq, S. Ali, M. N. Tahir, H. Ismail, B. Mirza, M. Saadiq, M. A. Haleem, M. Iqbal, Acta Chim. Slov. 2017, 64, 397-408. DOI: $10.17344 /$ acsi.2017.3250

26. O. Castillo, A. Luque, S. Iglisias, C. Guzman-Miralles, P. Roman, Inorg. Chem. Commun. 2001, 4, 640-642. DOI:10.1016/S1387-7003(01)00291-X

27. P. Phuengphai, S. Youngme, N. Chaichit, C. Pakawatchai, G.A. Albada, M. Quesada, J. Reedijk, Polyhedron 2006, 25, 2198-2206. DOI:10.1016/j.poly.2006.01.014

28. M. A. Halcrow, Chem. Soc. Rev. 2013, 42, 1784-1795. DOI:10.1039/C2CS35253B

29. M. Iqbal, S. Ali, M. N. Tahir, Acta Chim. Slov. 2018, 65, 131137. DOI:10.17344/acsi.2017.3702

30. G. S. Baghel, J.P. Chinta, A. Kaiba, P. Guionneau, C.P. Rao, Cryst. Growth Des. 2012, 12, 914-926.

DOI: $10.1021 / \mathrm{cg} 2013683$ 
31. M. T. Carter, M. Rodriguez, A. J. Bard, J. Am. Chem. Soc. 1989, 111, 8901-8911. DOI:10.1021/ja00206a020

32. M. S. Mohamed, A. A. Shoukry, A. G. Ali, Spectrochim. Acta Part A 2012, 86, 562-570. DOI:10.1016/j.saa.2011.11.015

33. K. Abdi, H. Hadadzadeh, M. Weil, M. Salimi, Polyhedron 2012, 31, 638-648. DOI:10.1016/j.poly.2011.10.028

34. Q. X. Wang, F. Gao, K. Jiao, Electroanalysis 2008, 20, 20962099. DOI:10.1002/elan.200804291

35. Q. Feng, N.Q. Li, Y. Y. Jiang, Anal. Chim. Acta 1997, 344, $97-$ 104. DOI:10.1016/S0003-2670(97)00008-1

36. J. L. Garcia-Gimenez, J. Hernandez-Gil, A. Martınez-Ruız, A. Castineiras, M. Liu-Gonzalez, F.V. Pallardo, J. Borras, G.A. Pina, J. Inorg. Biochem. 2013, 121, 167-178.

DOI:10.1016/j.jinorgbio.2013.01.003

37. K. Suntharalingam, D. J. Hunt, A. A. Duarte, A. J. P. White, D. J. Mann, R. Vilar, Chem. Eur. J. 2012, 18, 15133-15141. DOI:10.1002/chem.201202482

38. A. M. Angeles-Boza, P. M. Bradley, P. K.-L. Fu, S. E. Wicke, J. Bacsa, K. R. Dunbar, C. Turro, Inorg. Chem. 2004, 43, 8510-8519. DOI:10.1021/ic049091h

39. J. Wang, Analytical Electrochemistry, 1st ed., VCH Publishers, 1994, pp. 165-166.

40. A. J. Bard, L. R. Faulkner, Electrochemical Methods, Fundamentals and Applications, 2nd ed., Wiley, New York, 2004, pp. 236.

41. M. Chauhan, K. Banerjee, F. Arjmand, Inorg. Chem. 2007, 46, 3072-3082. DOI:10.1021/ic061753a

DOI:10.1016/j.jinorgbio.2012.09.019
42. G.-Y. Li, K.-J. Du, J.-Q. Wang, J.-W. Liang, J.-F. Kou, X.-J. Hou, L.-N. Ji, H. Chao, J. Inorg. Biochem. 2013, 119, 43-53.

43. S. Majumder, M. Fleck, C. R. Lucas, S. Mohanta, J. Mol. Struct. 2012, 1020, 127-133. DOI:10.1016/j.molstruc.2012.04.003

44. V. Rajendiran, R. Karthik, M. Palaniandavar, H. Stoeckli-Evans, V. S. Periasamy, M. A. Akbarsha, B.S. Srinag, H. Krishnamurthy, Inorg. Chem. 2007, 46, 8208-8221. DOI:10.1021/ic700755p

45. M. Saif, M. M. Mashaly, M. F. Eid, R. Fouad, Spectrochim. Acta Part A 2012, 92, 347-356.

DOI:10.1016/j.saa.2012.02.098

46. E. Q. Procopio, T. Fukushima, E. Barea, J. A. R. Navarro, S. Horike, S. Kitagawa, Chem. Eur. J. 2012, 18, 13117-13125. DOI: $10.1002 /$ chem. 201201820

47. L. Jia, J. Shi, Z.-H. Sun, F.-F. Li, Y. Wang, W.-N. Wu, Q. Wang, Inorg. Chim. Acta 2012, 391, 121-129. DOI:10.1016/j.ica.2012.05.014

48. X. Li, Y.-T. Li, Z.-Y. Wu, Y.-J. Zheng, C.-W. Yan, Inorg. Chim. Acta 2012, 385, 150-157. DOI:10.1016/j.ica.2012.01.047

49. M.Y. Ni, Y. Wang, H.L. Li, Pol. J. Chem. 1997, 71, 816-822.

50. P. Zivec, F. Perdih, I. Turel, G. Giester, G. Psomas, J. Inorg. Biochem. 2012, 117, 35-47.

DOI:10.1016/j.jinorgbio.2012.08.008

51. A. Kellett, O. Howe, M. O'Connor, M. McCann, B. S. Creaven, S. McClean, A. F.-A. Kia, A. Casey, M. Devereux, Free Radical Biol. Med. 2012, 53, 564-576.

DOI:10.1016/j.freeradbiomed.2012.05.034

\section{Povzetek}

Sintetizirali smo dvojedrni centrosimetrični bakrov(II) kompleks in ga okarakterizirali z FT-IR, UV-vidno in EPR spektroskopijo, praškovno in monokristalno XRD analizo ter elektrokemijsko metodo. Dva bakrova(II) iona sta povezana preko dveh $\mu$-1,1-O atomov $p$-fluorofenilacetatnega liganda. Vsak bakrov(II) ion je koordiniran $\mathrm{z}$ dvema monodentatnima karboksilatnima ligandoma in bidentatno $\mathrm{z}$ molekulo 2,2'-bipiridina. Geometrija okoli pentakoordiniranega bakrovega(II) iona je kvadratno piramidalna s faktorjem popačenja $\tau=0.04$. Čistost in uniformnost kristaliničnega produkta je bila ugotovljena $\mathrm{z}$ praškovnim XRD posnetkom. EPR signal ima delno razrešljivo hiperfino strukturo, medtem ko elektrokemijske študije kažejo na difuzijsko kontroliran prenos elektrona $\mathrm{z}$ difuznim koeficientom $1.628 \times 10^{-7} \mathrm{~cm}^{2} \mathrm{~s}^{-1}$. Rezultati spektroskopskih eksperimentov so si v soglasju. Kompleks se veže na DNA z veznima konstantama $3.667 \times 10^{4}$ in $1.438 \times 10^{4} \mathrm{M}^{-1}$, kot je določeno s ciklično voltametrijo oziroma absorpcijsko spektroskopijo. Preliminarni rezultati kažejo na strukturno in biološko pomembnost pripravljenega kompleksa. 